\title{
SIMULASI NUMERIK \\ SISTEM PANAS BUMI BITTUANG \\ KABUPATEN TANATORAJA, SULAWESI SELATAN
}

\author{
Oleh: \\ Dikdik Risdianto, Dudi Hermawan, Dedi Kusnadi, Muhammad Kholid, dan Yuano Rezky \\ Pusat Sumber Daya Geologi \\ Jalan Soekarno-Hatta No.444, Bandung
}

\begin{abstract}
SARI
Simulasi numerik di daerah panas bumi Bittuang menggunakan program simulator TOUGH2 dengan Equation of State (EOS1), satu fasa, disusun berdasarkan konseptual model hasil survey geologi, geokimia, geofisika (3-G) dan pengeboran landaian suhu sumur BTG-1. Parameter yang digunakan antara lain permeabilitas, porositas, konduktivitas panas serta kapasitas panas batuan.

Susunan penyebaran litologi secara lateral dan vertikal berdasarkan grid blok serta tersusun menjadi beberapa lapisan mendekati model konseptual. Kondisi inisial dan batas kondisi diberikan berdasarkan data-data yang tersedia.

Hasil simulasi yang didapatkan setelah mengalami proses uji coba beberapa kali dengan merubah beberapa parameter simulasi dan hasil yang paling baik dikalibrasi dengan hasil pengukuran temperatur sumur pengeboran landaian suhu BTG-1 serta kemunculan manifestasi permukaan. Mengingat keterbatasan data yang dimiliki, hasil simulasi ini merupakan proses inisial (permulaan) simulasi untuk sistem panas bumi Bittuang dan masih harus dilakukan update berdasarkan data lanjutan.
\end{abstract}

Kata kunci: Bittuang, kondisi inisial, kondisi natural, panas bumi, simulasi numerik.

\section{ABSTRACT}

Numerical simulations in Bittuang geothermal area use TOUGH2 simulator program with Equation of State 1 (EOS-1), single phase, and based on a conceptual model of geological, geochemical, geophysical surveys (3 - G) result and also the temperature slope drilling wells BTG-1. The parameters that involved in calculation are permeability, porosity, thermal conductivity and specific heat capacity.

Lithology of area is spread laterally and vertically based on grid of blocks and arrayed into several layers similar to the conceptual model. Initial condition and boundary are given based on the data available.

Simulation results are obtained after a process of testing several times by changing some parameters of the simulation and the best results with a calibrated by measured temperature of gradient thermal drilling wells BTG-1 and also by the presence of the surface manifestations. Due to the limitation of the data especially deep drilling data, the results of simulation is needed to be updated by advanced data.

Keywords: Bittuang, initial condition, natural state, geothermal, numeric simulation.

\section{PENDAHULUAN}

Salah satu tujuan dari simulasi numerik sistem panas bumi adalah menguji kemungkinan keberadaan suatu sistem panas bumi yang terbentuk dalam suatu konseptual model. Hal ini sangat penting dilakukan terutama pada suatu daerah panas bumi yang masih belum dieksploitasi (natural state) dan masih belum banyak memiliki data bawah permukaan yang lengkap (pengeboran eksplorasi). 


\section{MAKALAH ILMIAH}

Secara administratif daerah penyelidikan panas bumi Bittuang termasuk dalam wilayah Kecamatan Bittuang, Kabupaten Tanatoraja, Provinsi Sulawesi Selatan, pada koordinat antara $119^{\circ} 36^{\prime}$ $56,52^{\prime \prime}-119^{\circ} 45^{\prime} 08,64$ " BT dan $2^{\circ} 51^{\prime}$ '50,76" LS - $3^{\circ} 0^{\prime} 05,40^{\prime \prime}$ LS, dengan luas sekitar 15 $\mathrm{km} \times 15 \mathrm{~km}$. Berada di sebelah utara kota Makassar, ibukota Provinsi Sulawesi Selatan, berjarak sekitar $360 \mathrm{~km}$. Lokasi penyelidikan dapat dicapai mengunakan pesawat terbang sampai ke Makassar, dilanjutkan dengan kendaraan roda empat sampai ke Bittuang.

Sistem panas bumi Bittuang tersusun oleh batuan vulkanik Kuarter. Pada zaman Kuarter terjadi di daerah ini terjadi aktivitas vulkanik pembentukan Gunung Karua yang ditandai dengan tersingkapnya satuan lava Karua-1 dan satuan lava Karua-2. Kemudian aktivitas vulkanik mencapai puncaknya dengan terjadinya erupsi Gunung Karua

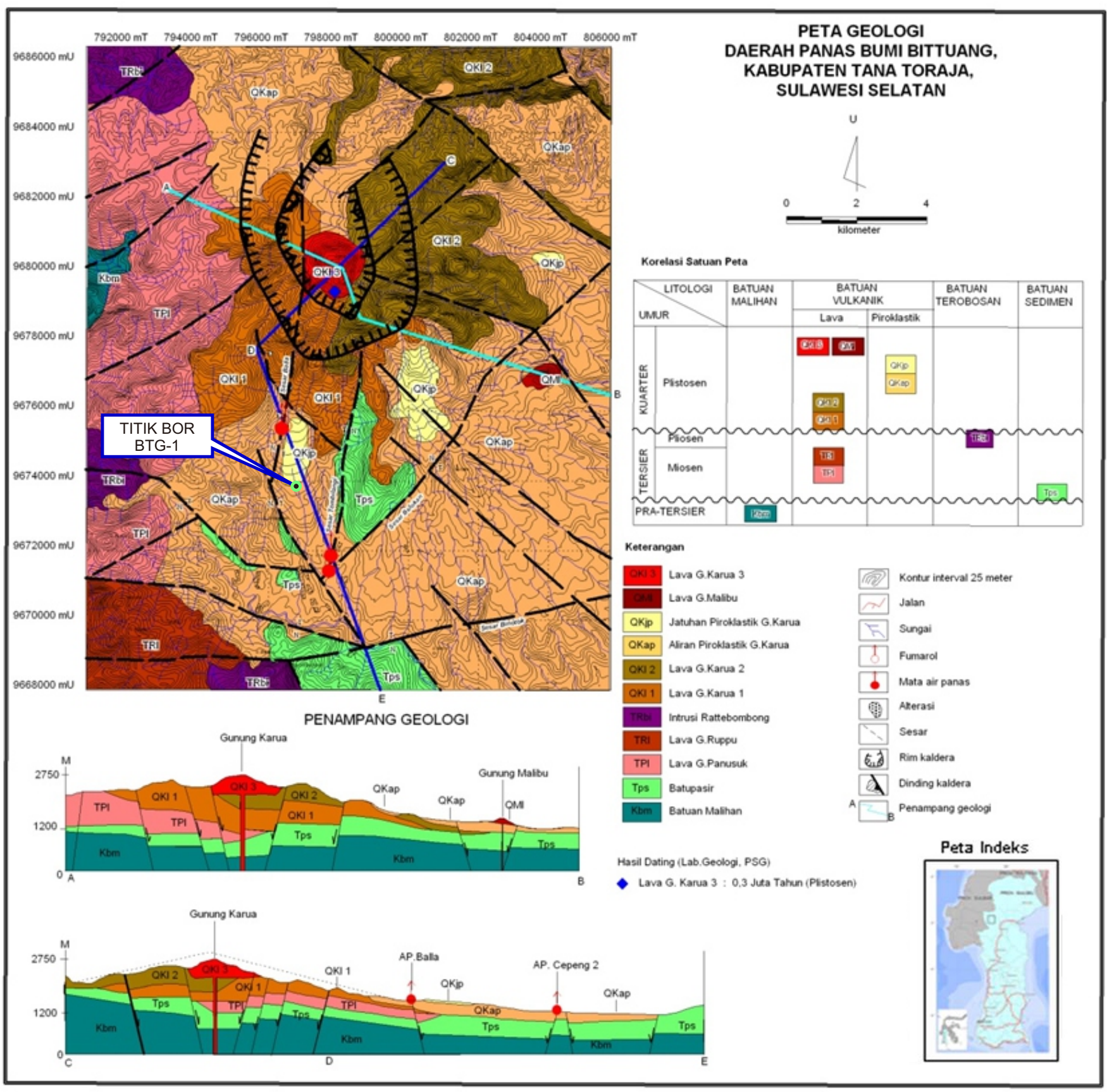

Gambar 1. Peta Geologi daerah panas bumi Bittuang, Kab. Tanatoraja, Sulawesi Selatan (Anonim, 2009) 
yang menghasilkan produk aliran piroklastik dan jatuhan piroklastik. Lama setelah erupsi berlangsung, terjadi kekosongan di dalam perut bumi yang ditandai dengan adanya runtuhan atau amblas di puncak Gunung Karua yang membentuk struktur rim kaldera. Aktivitas magmatik terus berlangsung sehingga membentuk kubah lava muda (lava Gunung Karua-3) di dalam kaldera tersebut. Aktivitas magmatik tersebut juga muncul di luar sistem kaldera tersebut dan membentuk kubah lava Gunung Malibu yang merupakan suatu parasit dari Gunung Karua.

Penyebaran manifestasi panas bumi di daerah penyelidikan berada di zona depresi sempit di sebelah selatan Gunung Karua yang pemunculannya dikontrol oleh sesar-sesar normal yang berarah baratlauttenggara, baratdaya-timurlaut dan hampir utara-selatan. Manifestasi di daerah Bittuang ini berupa pemunculan fumarol, mata air panas, batuan ubahan dan bekas lapangan solfatara.

Dari analisis geologi, daerah panas bumi Bittuang sangat menarik, karena berhubungan erat dengan lingkungan geologi vulkanik Kuarter. Di lokasi ini manifestasi berasosiasi dengan aktivitas vulkanik yang berumur $\pm 0,3-0,1$ juta tahun atau pada Kala Plistosen (Gambar 1 ).

Struktur geologi utama berarah relatif utara-selatan, mengontrol pembentukan manifestasi permukaan di daerah Balla dan Cepeng.

Beberapa manifestasi berupa mata air panas dijumpai di lokasi ini. Manifestasi panas bumi dapat dikelompokkan menjadi dua yaitu manifestasi Balla dan Cepeng. Di kelompok manifestasi Balla tercium bau $\mathrm{H}_{2} \mathrm{~S}$, terdapat sublimasi belerang, temperatur tertinggi $96,7^{\circ} \mathrm{C}$. Di sekitar manifestasi ini, terdapat mata air panas bertemperatur antara $48,1-96,7^{\circ} \mathrm{C}$, dengan temperatur udara $22,5^{\circ} \mathrm{C}, \mathrm{pH} 8,40$ dan debit 1 liter/detik. Air panas berwarna jernih, berasa asin, terdapat bualan gas, tercium bau belerang, dan terdapat endapan sinter silika.

Sedangkan di kelompok manifestasi Cepeng air panas muncul dari celah batuan piroklasitk dengan temperatur $39,8^{\circ} \mathrm{C}$, pada temperatur udara $20,1^{\circ} \mathrm{C}, \mathrm{pH} 5,97$ dan debit $2 \mathrm{l} /$ detik. Air panas berwarna jernih, rasa masam, tidak terdapat bualan gas, terdapat oksidasi besi, dan tidak terdapat endapan sinter.
Mempertimbangkan karakteristik manifestasi panas bumi di daerah Bittuang yang berupa mata air panas bertemperatur tinggi $\left(96^{\circ} \mathrm{C}\right)$, terdapat sinter silika, bertipe klorida, dan didukung dengan pengkayaan oksigen 18, maka temperatur bawah permukaan yang berhubungan dengan reservoir panas bumi diperkirakan sekitar $200^{\circ} \mathrm{C}$. Konsentrasi $\mathrm{Hg}$ (merkuri) tanah relatif tinggi lebih dari $240 \mathrm{ppb}$ mendukung posisi zona upflow di sekitar Balla yang memanjang dengan arah barat laut tenggara, sedangkan mata air panas kelompok Cepeng, merupakan outflow dari sistem panas bumi Bittuang.

\section{KONSEPTUAL MODEL}

Konseptual model adalah suatu gambaran model berdasarkan dari data geosain yang dihasilkan dari survei geologi, geokimia, geofisika dan pengeboran. (Gambar 2).

Secara umum sistem panas bumi Bittuang berasosiasi dengan produk komplek gunung api Gunung Karua yang berumur Kuarter, zona upflow berada di lereng Gunung Karua, aliran fluida secara lateral dikontrol oleh struktur utama yang berarah relatif utara-selatan hingga keluar sebagai kelompok manifestasi permukaan di daerah Cepeng. Lapisan resistivitas rendah diinterpretasikan sebagai lapisan penudung (cap rock) berdasarkan hasil survei magnetotellirik (Anonim, 2012 ), sedangkan sumber panas atau heat sources diperkirakan berasal dari sisa aktivitas Gunung Karua.

\section{METODE SIMULASI NUMERIK}

Pada umumnya simulasi numerik atau simulasi reservoir dilakukan pada lapangan-lapangan panas bumi yang siap dikembangkan, pada lapangan-lapangan ini tujuan simulasi ini lebih diarahkan pada prediksi produksi dari sumur-sumur produksi yang akan diproduksikan, sehingga hasil simulasi ini bisa menunjang skenario pengembangan lapangan panas bumi.

Mengingat keterbatasan data yang ada, pada kasus simulasi numerik Daerah Bittuang ini, tujuan simulasi hanya menguji konseptual model, yang telah dihasilkan dari survei-survei geosain sebelumnya, kalibrasi 


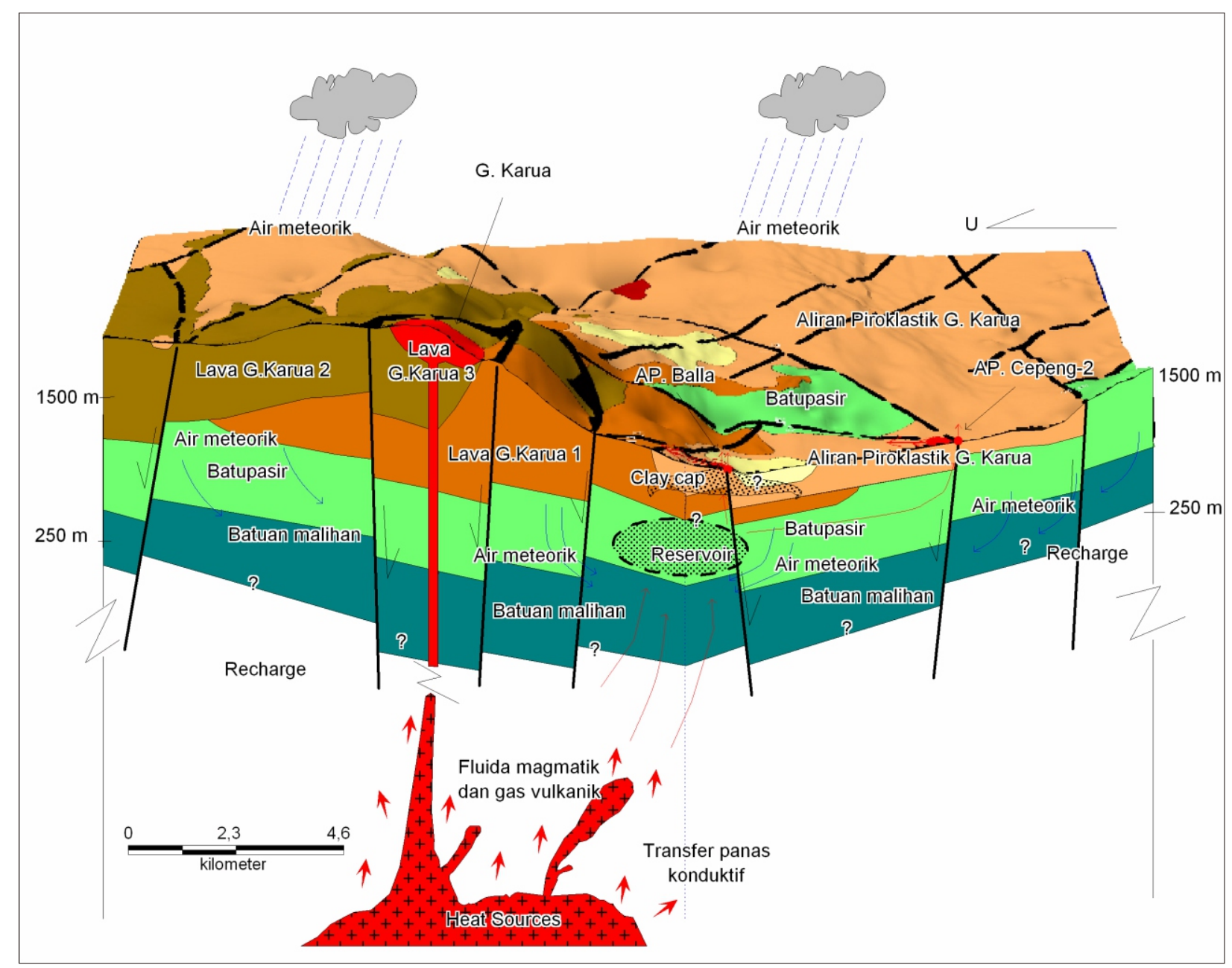

Gambar 2. Konseptual model sistem panas bumi Bittuang (Anonim, 2012)

hasil simulasi hanya berupa kurva landaian suhu yang hasilkan dari pengukuran temperatur sumur pengeboran landaian temperatur BTG-1, sehingga validitas hasil simulasi belum maksimal, tetapi hasil simulasi ini bisa memberi gambaran awal dari suatu sistem yang ada di daerah panas bumi Bittuang.

Simulasi numerik sistem panas bumi Bittuang mengacu pada konseptual model yang didapat dari survei geosain. Model konseptual 3-D disusun berdasarkan parameter-parameter sifat litologi yang dipandu oleh penyebaran litologi secara lateral atau vertikal dari konseptual model. Model numerik 3 dimensi (3-D) ini disesuaikan parameter-parameternya berkali-kali secara trial and error hingga didapatkan kondisi natural state reservoir yang sesuai (matching) dengan parameter hasil pengukuran logging temperatur dari sumur pengeboran landaian suhu BTG-1.

\section{Sistem Grid dan Perlapisan}

Pada prinsipnya, metode simulasi numerik adalah membuat parameterparameter geosain menjadi suatu susunan angka, sistem yang digunakan adalah dengan membuat blok grid-grid.

Untuk simulasi ini dibuat dengan dimensi $7 \mathrm{~km}$ (arah barat-timur) dan 9,5 km (arah utara-selatan) sedangkan secara vertikal sedalam $1700 \mathrm{~m}$ atau pada elevasi $200 \mathrm{~m}$ di bawah permukaan laut (Gambar 3). Tebal perlapisan blok-blok dengan grid bervariasi antara 50 hingga $250 \mathrm{~m}$, elevasi top model simulasi diambil pada elevasi $1400 \mathrm{~m}$ di atas permukaan laut. Penentuan dimensi grid dibuat berdasarkan kondisi geosain dari konseptual model, umumnya di zone-zone struktur dan manifestasi serta titik pengeboran. Dimensi grid bisa dipersempit hingga mencapai ukuran $250 \mathrm{~m} \times 250 \mathrm{~m}$.

Proses simulasi numerik dilakukan dengan program simulasi TOUGH2 v.2, 


\section{MAKALAH ILMIAH}

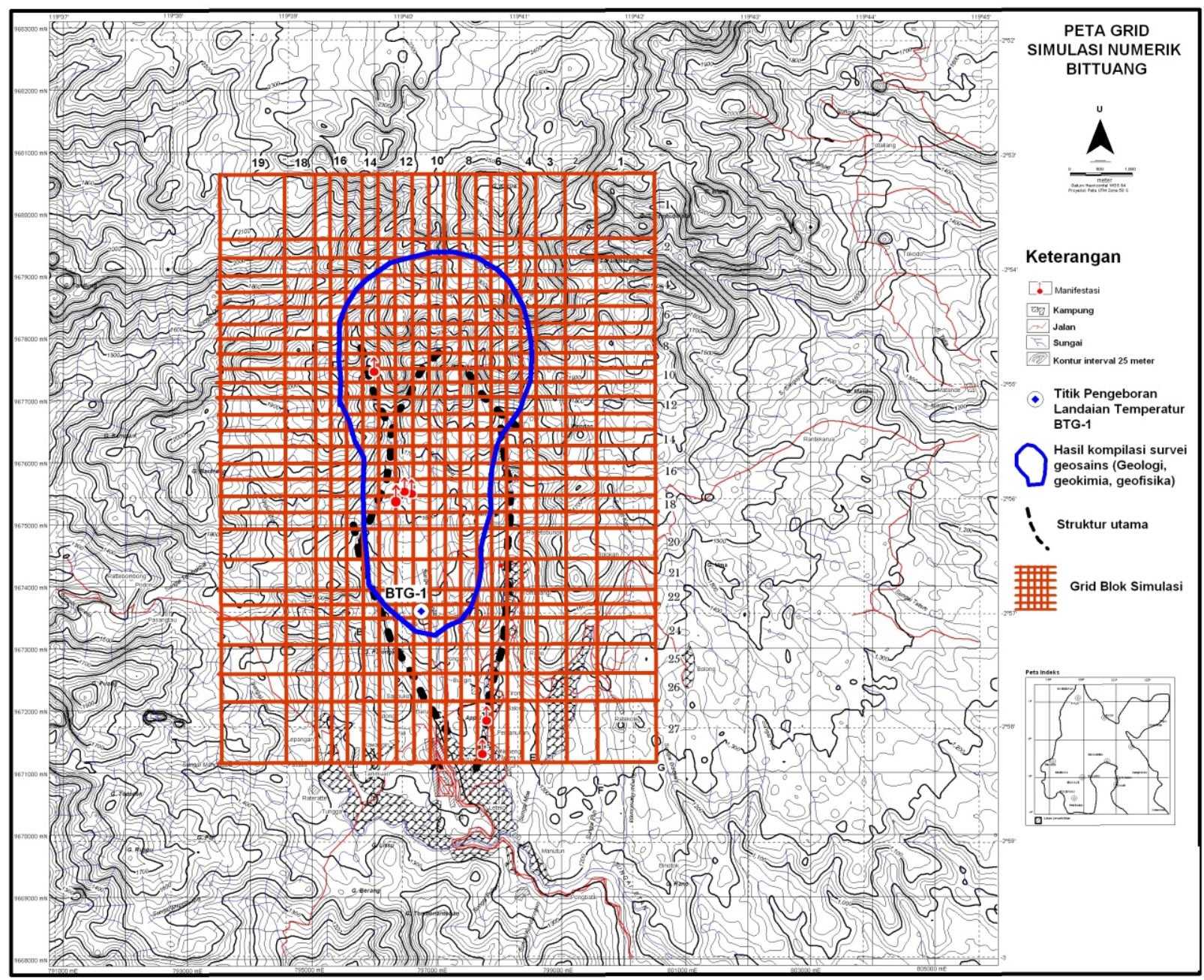

Gambar 3. Peta grid blok simulasi numerik sistem panas bumi Bittuang (Anonim, 2012)

dilengkapi oleh Equation of State 1 (EOS 1 ), dengan asumsi sistem terdiri dari satu fase. Sebelum melakukan proses kalkulasi dengan simulator TOUGH2 terlebih dahulu dilakukan pemrosesan dengan program PrePost Processor yang merupakan program makro spread sheet Microsoft Excel.

TOUGH2 (Transport of Unsaturated Groundwater and Heat) adalah program simulasi yang melibatkan fluida, mineral tracer dan transfer panas. Penggunaannya sendiri sangat luas antara lain dalam perminyakan, panas bumi, pembuangan limbah reaktor nuklir, pengelolaan limbah dan sebagainya (Pruess, et al., 1999)

Dalam kalkulasinya, TOUGH2 menggunakan kalkulasi keseimbangan massa dan panas (heat and mass balance) yang menggambarkan sifat fluida dan aliran panas. Dalam aplikasinya di bidang panas bumi terutama pada lapangan yang sudah produksi, simulasi ini dapat menghitung cadangan (reserved) energi panas bumi lebih akurat, sehingga hasil dari simulasi ini dapat dijadikan acuan dalam skenario pembangkitan listrik.

\section{Parameter Litologi}

Parameter-parameter petrofisik yang digunakan dalam proses simulasi terdiri dari densitas, permeabilitas, konduktivitas termal, porositas dan kandungan panas. Satuan parameter-parameter ini semua dinyatakan dalam satuan SI (Sistem International). Parameter-parameter ini menyebar secara lateral dan vertikal berdasarkan konseptual model yang digunakan. Lapisan reservoir atau zona struktur sesar memiliki sifat permeabilitas relatif lebih tinggi dibandingkan lainnya, sebaliknya untuk lapisan penudung (cap rock) memiliki nilai permeabilitas jauh lebih 
rendah, sehingga fluida tidak bisa melewati lapisan ini. Parameter permeabilitas yang digunakan dalam simulasi ini berkisar antara 0,01 hingga $100 \times 10^{-5} \mathrm{~m}^{2}$.

Parameter lainnya seperti porositas diestimasi bersifat homogen yaitu sekitar $10 \%$, densitas batuan juga dianggap homogen yaitu $2500 \mathrm{~kg} / \mathrm{m}^{3}$ yang mewakilli litologi vulkanik dan sedimen, termal konduktivitas dan kapasitas panas juga estimasi homogen yaitu masing masing 2,5 $\mathrm{W} / \mathrm{m}^{\circ} \mathrm{C}$ dan $1000 \mathrm{~J} / \mathrm{kg}^{\circ} \mathrm{C}$. Tabel 1 memperlihatkan parameter petrofisik yang digunakan dalam simulasi.

\section{Kondisi Inisial dan Kondisi Batas}

Simulasi pada kondisi natural state adalah mensimulasikan kondisi sistem pada saat belum diproduksi atau dieksploitasi, Simulasi ini dijalankan dengan rentang waktu sekitar 1.000.000 tahun, hal ini diharapkan sistem sudah mencapai kesetimbangan (Nakatani et.al, 2007). yaitu sekitar $25^{\circ} \mathrm{C}$. Selain itu di bagian sisi selatan yang terletak di luar sistem panas bumi Bittuang penyebaran temperatur secara vertikal mengikuti gradien temperatur normal yaitu sekitar $4^{\circ} \mathrm{C} / 100 \mathrm{~m}$ dan besarnya tekanan mengikuti tekanan hidrostatiknya yang merupakan fungsi dari kedalaman dan densitas air. Sumber panas diletakkan tepat di bawah zone reservoir dengan temperatur antara $180^{\circ}$ hingga $210^{\circ} \mathrm{C}$, berdasarkan hasil geotermometer (Anonim, 2009).

\section{PEMBAHASAN HASIL SIMULASI}

Hasil simulasi merupakan hasil terbaik hasil uji coba selama beberapa kali, dengan cara memodifikasi nilai-nilai parameter serta geometri dari blok grid yang dibuat. Hasil ini dikalibrasi oleh hasil pengukuran temperatur sumur pengeboran landaian suhu BTG-1 dan manifestasi yang terbentuk di permukaan hasil yang paling sesuai (matching) dengan hasil pengukuran

Tabel 1. Parameter litologi yang digunakan dalam proses simulasi.

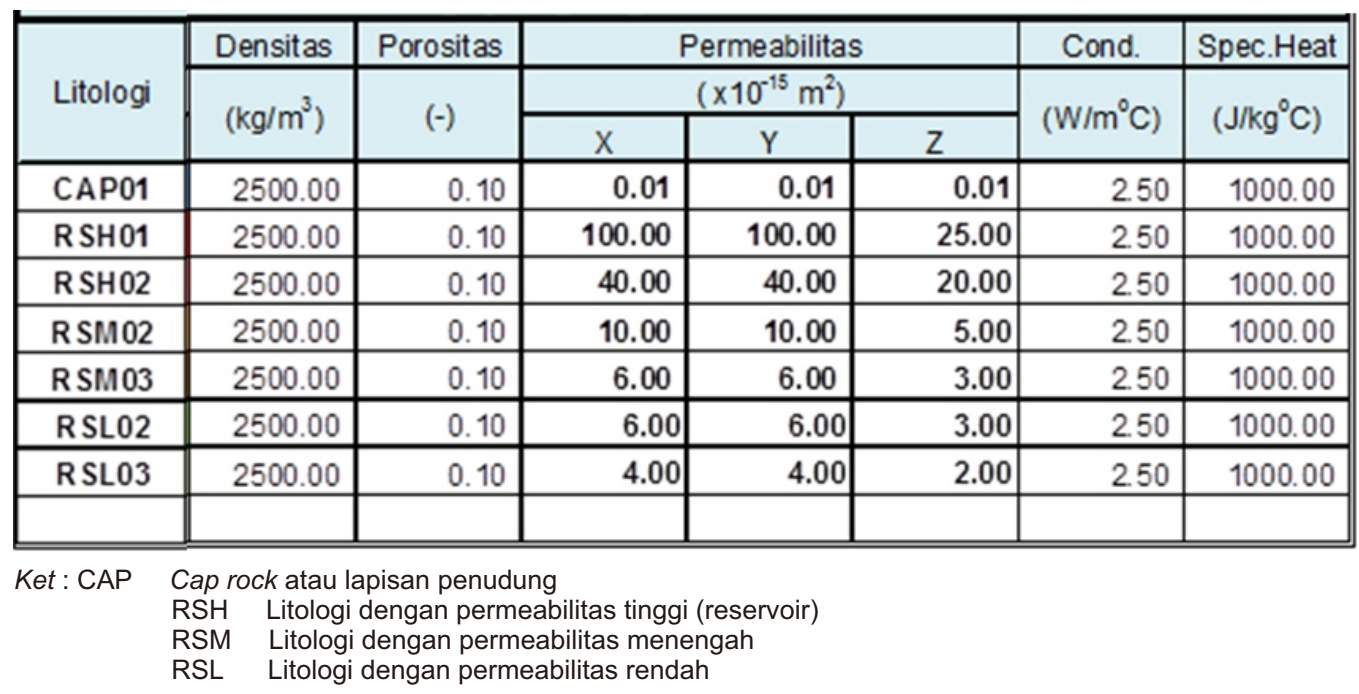

Kondisi inisial dan kondisi batas yang diterapkan dalam simulasi ini adalah tekanan yang di asumsikan bergradasi mulai dari sisi selatan dan membesar nilainya ke arah sisi utara, mulai dari 1 bara hingga 20 bar. Penentuan nilai tekanan ini didasarkan pada tekanan hidrostatik. Dengan adanya perbedaan tekanan ini sistem akan mengalir dari utara ke selatan, sedangkan untuk temperatur kondisi inisial di puncak blok pemodelan diasumsikan besarnya sama yang dianggap mendekati sistem yang disimulasikan.

Secara umum sistem panas bumi Bittuang, berdasarkan sebaran temperatur $\left({ }^{\circ} \mathrm{C}\right)$ hasil simulasi berada di lereng barat daya Gunung Karua. Struktur geologi yang berarah utara-selatan mengontrol aliran fluida panas ke arah selatan sehingga di Cepeng muncul manifestasi berupa mata air panas (Gambar 4a, 4b dan 4c). 

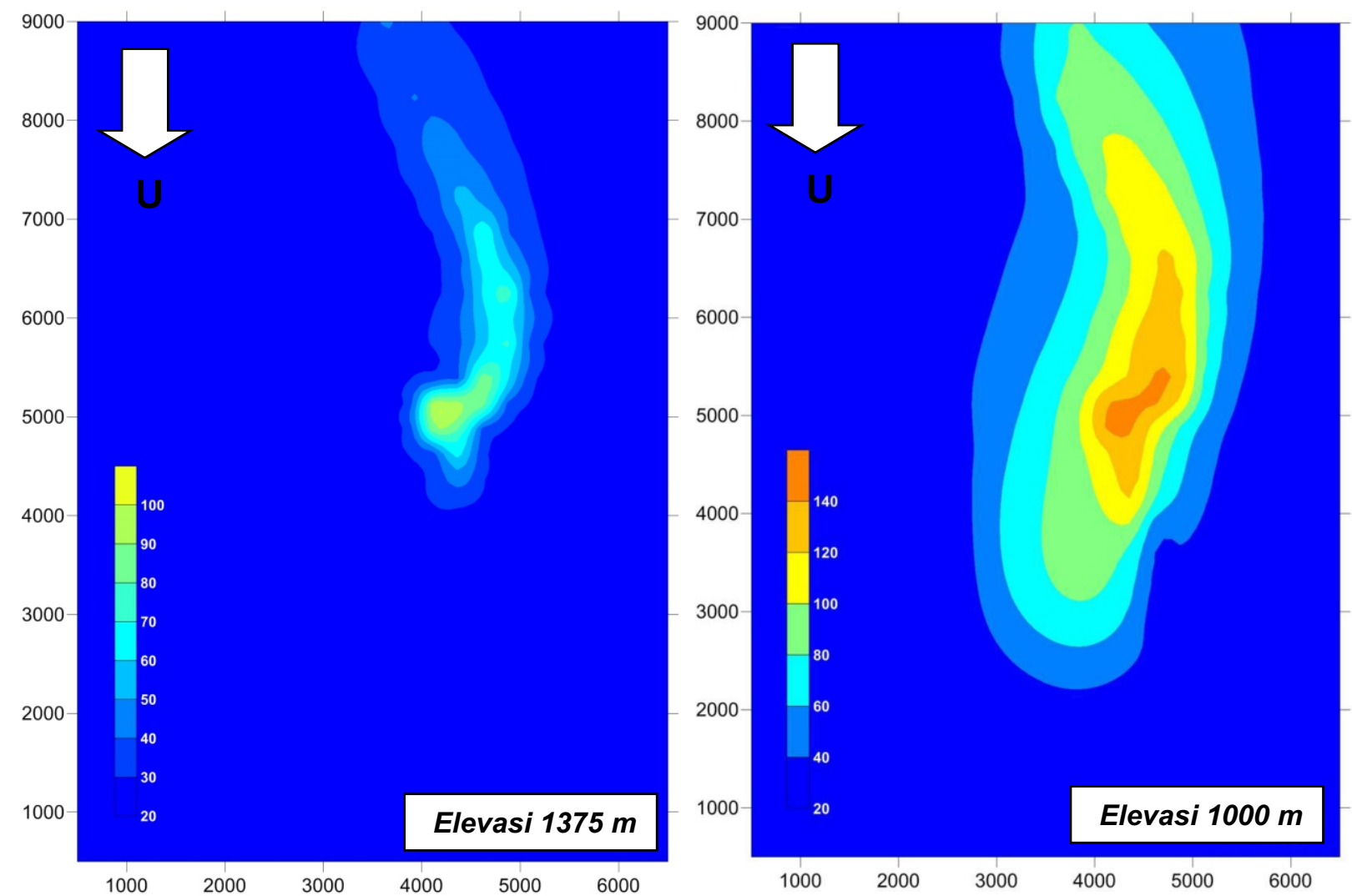

Gambar 4a. Distribusi temperatur pada elevasi 1375 dan $1000 \mathrm{~m}$ di atas muka laut
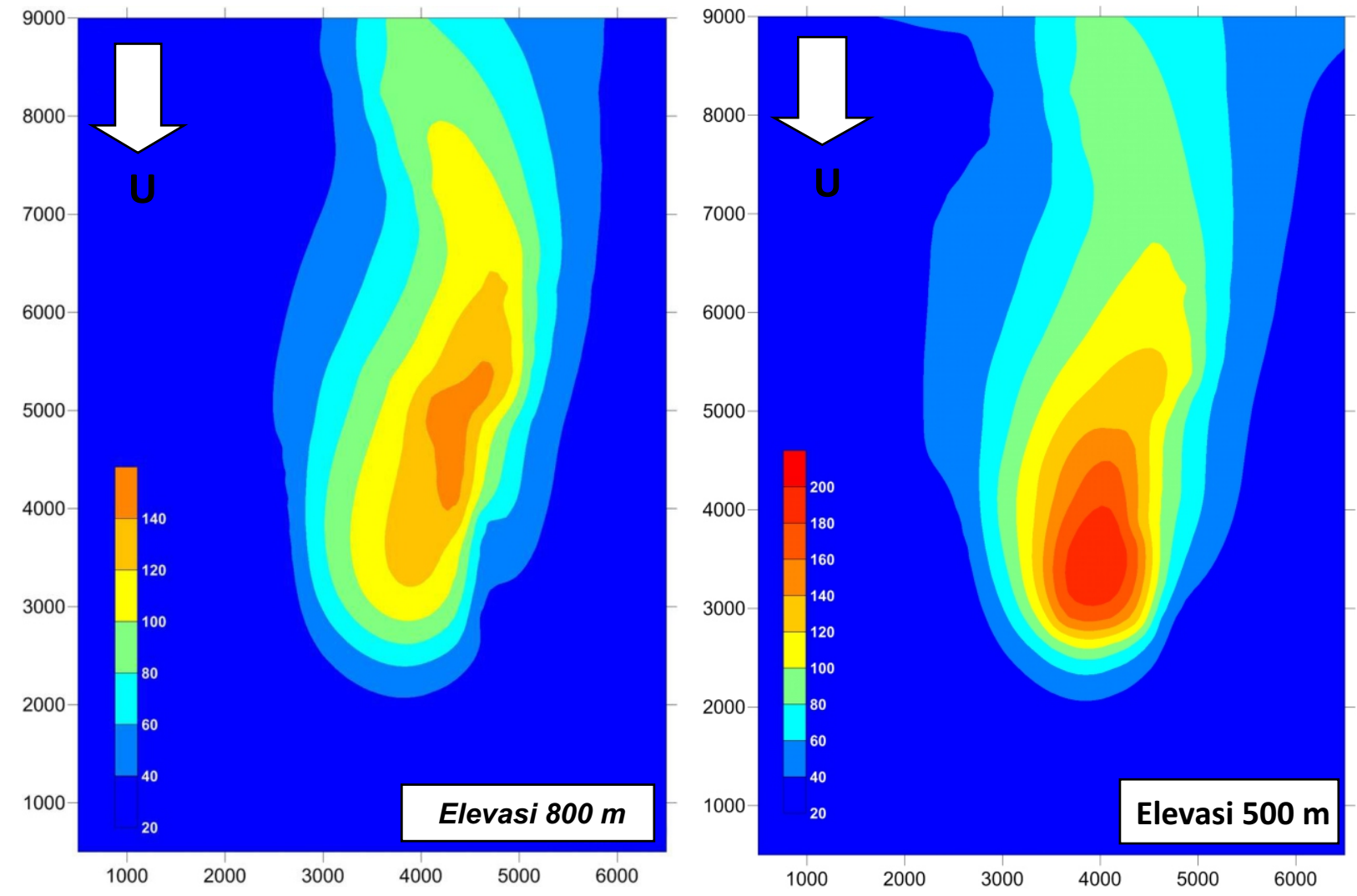

Gambar 4b. Distribusi temperatur pada elevasi 800 dan $500 \mathrm{~m}$ di atas muka laut 

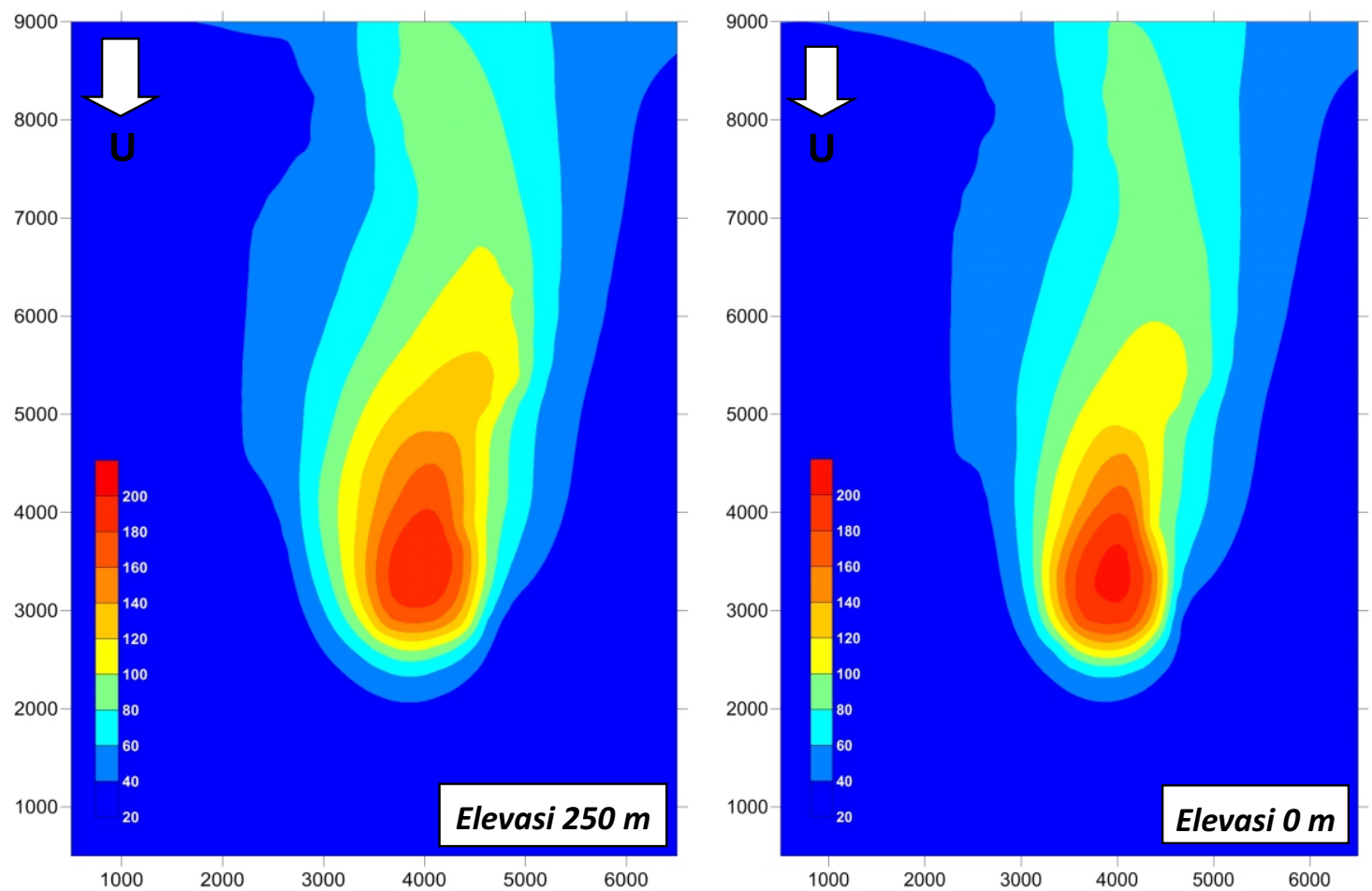

Gambar 4c. Distribusi temperatur pada elevasi 250 dan $0 \mathrm{~m}$ di atas muka laut

Hasil komparasi dari distribusi temperatur secara vertikal antara hasil simulasi dengan hasil pengukuran temperatur di sumur landaian suhu BTG-1, terlihat diantara keduanya (Gambar 5). Kesesuaian (matching) juga diperlihatkan dalam penampang yang memotong sistem panas bumi Bittuang yang menunjukkan bahwa sebaran panas berada di bawah manifestasi permukaan (air panas, tanah panas, batuan ubahan) Balla (Gambar 6).

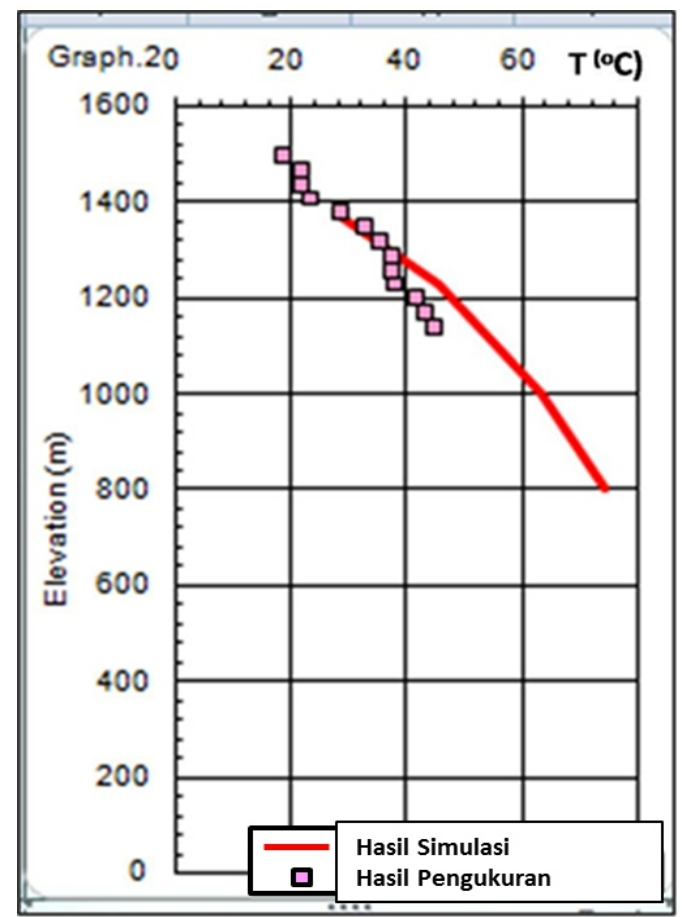

Gambar 5. Komparasi hasil simulasi dengan hasil pengukuran downhole temperatur sumur landaian suhu BTG-1. 


\section{MAKALAH ILMIAH}

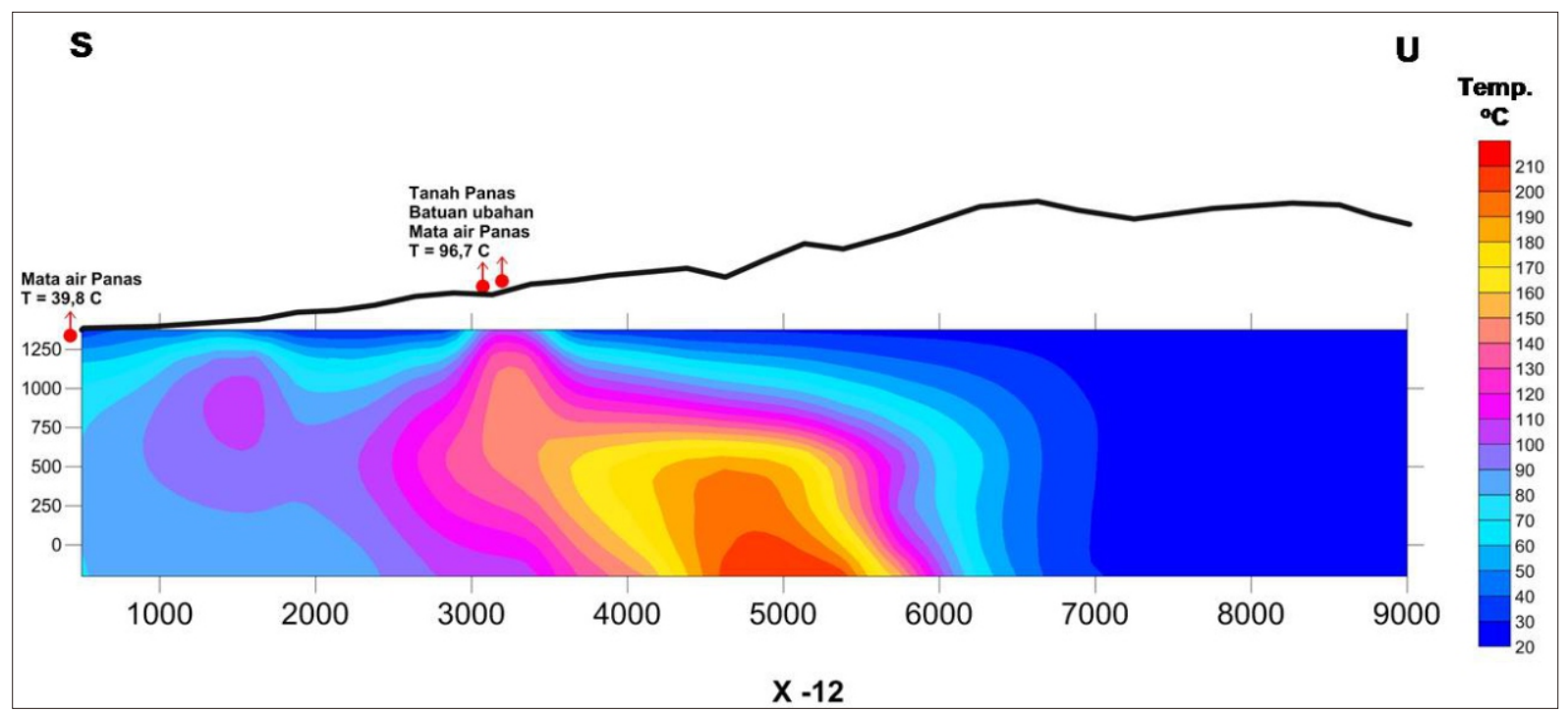

Gambar 6. Komparasi hasil simulasi dengan manifestasi permukaan.

\section{KESIMPULAN}

Simulasi numerik sistem panas bumi Bittuang merupakan bentuk dari proses modifikasi suatu konseptual ke dalam bentuk data numerik, dimana hasil kesesuaian dari hasil simulasi dan data pengukuran yang paling sesuai adalah merupakan hasil yang mendekati sistem yang disimulasikan.

Kesesuaian (matching) antara hasil simulasi dengan hasil pengukuran temperatur pada sumur landaian temperatur BTG-1 serta kesesuaian antara distribusi temperatur dengan manifestasi panas bumi di permukaan mengindikasikan bahwa hasil simulasi yang didapat menggambarkan secara lebih jelas sistem panas panas bumi Bittuang lebih jelas.

Hasil simulasi menunjukkan bahwa sistem panas bumi berada di lereng barat daya Gunung Karua, fluida mengalir dari reservoir ke arah selatan yang dikontrol oleh struktur geologi berarah relative relatif utaraselatan.

\section{UCAPAN TERIMAKASIH}

Penulis ucapkan terima kasih kepada semua pihak yang mendukung proses penulisan tulisan ini, terutama kepada para tim survei geosain yang telah menghasilkan data-data sebagai bahan untuk simulasi, juga kepada Hiroyuki Tokita dan Koichiro Fukuoka yang telah berbagi pengetahuan tentang simulasi numerik dalam program kerja sama antara Badan Geologi dalam hal ini Pusat Sumber Daya Geologi dengan JICA.

\section{DAFTAR PUSTAKA}

Anonim. 2009. Survei Terpadu Geologi, Geokimia dan Geofisika Daerah Panas Bumi Bittuang, Kabupaten Tanatoraja, Sulawesi Selatan. Pusat Sumber Daya Geologi, Badan Geologi.

Anonim. 2012. Survei Magnetotellurik (MT) Daerah Panas Bumi Bittuang, Kabupaten Tanatoraja, Sulawesi Selatan. Pusat Sumber Daya Geologi, Badan Geologi.

Nakatani, A., Itoi, R., Gotoh, H. and Tanaka, T. 2007. Development of Numerical Model of Takigami Geothermal Reservoir, Kyushu, Japan, Using TOUGH2 Simulator. Proceedings, 29th NZ Geothermal Workshop.

Pruess, K., Oldenburg, C., Moridis, G. 1999. TOUGH2 User's Guide, Version 2.0. Lawrence Berkeley National Laboratory. Report LBNL 43134, Berkeley, CA, USA. 